Mgr Ziemowit Janiak

UMCS Lublin

e-mail: ziemowit.janiak@gmail.com

\title{
Clarkson is a Woman, or about Gender in Language Illustrated by Interviews on the British Motoring Television Show Top Gear
}

\section{Introduction}

In the present article, we plan to investigate the notion of gender stereotypes based on the example of the linguistic analysis of interviews on the British motoring show Top Gear, carried out by the controversial journalist Jeremy Clarkson. We will look at the analysed phenomena from a sociolinguistic perspective.

The analysed material comes from earlier interviews carried out on Top Gear between 2008 and 2009. As we now know, Jeremy Clarkson was suspended and later dismissed on disciplinary grounds from the BBC after a fracas with the show producer Oisin Tymon on 9 march $2015^{1}$. It had not been the first controversy involving the well-known TV presenter. Clarkson has been accused of racism multiple times, and the journey to film a Christmas special in Patagonia ended with an international scandal because of the number plates on one of the cars that, according to some Argentineans, alluded to the 1982 Falklands War lost by Argentina ${ }^{2}$.

The choice of the TV show, as well as the TV presenter are not accidental. According to stereotypes, the subject matter in question, i.e. cars, is not a female domain. Consequently, it is presumed that women would have it harder to discuss topics related to the automotive industry. In other words, they would have problems to voice their opinions or the host would easily impose his style of interaction

1 Summary text of BBC's report into Jeremy Clarkson 'fracas', "The Guardian" [online], 25 March 2015. Available on the internet: www.theguardian.com/media/2015/mar/25/jeremyclarkson-fracas-report-full-text-bbc-macquarrie [accessed: 20 April 2015].

2 J. Plunkett, Top Gear driven from Argentina after Jeremy Clarkson number plate row, "The Guardian" [online], 3 October 2014. Available on the internet: www.theguardian.com/ media/2014/oct/03/top-gear-argentina-jeremy-clarkson-bbc [accessed: 20 April 2015]. 
on them. Obviously, the latter is related to Clarkson's traits of character and his worldview. He is known for his uncompromising character and conservative views. Clarkson can be viewed as 'a guardian of the patriarchal order'. To sum up, our aim is to examine if the ways interlocutors use language is shaped by their gender. That is, whether distinct differences in language use between men and women in fact exist.

It is worth noting that due to the limited volume of this article, we are not able to present a very detailed analysis of the language material and we point our readers' attention to the general conclusions that are the result of our studies. We refer the readers who are interested in the detailed analysis of the issues discussed in this article to our unpublished MA thesis under the title Man's Talk and Women's Talk in Selected "Top Gear" Interviews: in-between Gender and Function.

\section{Sex versus gender}

To begin with, we would like to explain certain differences of a linguistic and conceptual nature as well as define the notion of gender. In the English language there is a clear distinction between the notions of sex and gender. The former describes biological differences and is related to anatomical differences between men and women, including the reproductive system and the secondary sex characteristics, while the latter, i.e. gender, is mainly related to culture. While the first notion is quite obvious, the latter - in our opinion - needs further explication. According to the online version of the PWN Encyclopaedia (Encyklopedia PWN), gender is defined as one's self-identity in relation to gender roles and sexuality and is influenced by cultural and social norms and patterns. Moreover, according to PWNE, gender is learned and it begins developing in the process of early socialization from ages 3 to 6 when it begins to manifest itself 3 .

In other words, the way the roles of men and women are perceived in society (or by collective consciousness to be precise) is influenced by a plethora of various factors including history, culture, and various social processes. Quite obviously, constant changes occurring in society have an impact on gender roles. What is more, it is worth noting that - in the Polish context - with the increasing secularization and liberalisation of society the perception of other social roles is continuously changing and evolving towards the models seen in Western Europe (see: LGBT activism). Conservative ideals are slowly but surely giving way to modern progressiveness while new social structures are still emerging.

3 Pteć kulturowa, [in:] Encyklopedia PWN, [online]. Available on the internet: http://encyklopedia.pwn.pl/haslo/plec-kulturowa;3958385.html [accessed: 3 March 2015]. 
Summing up, according to many scholars, gender identity with all its consequences is a solely cultural construct. It is worth mentioning that in the Polish language the word gender is literally translated as cultural sex (pleć kulturowa). The present article is precisely concerned with this particular concept.

Scholars who explore the language-gender relationship can be divided into two main groups; the ones that believe that there are systematic differences between men and women in the way they use language and the ones that suggest that there are no such dissimilarities or that they are insignificant. In addition, it is worth mentioning that there is no total agreement among researchers who believe that the gender differences mentioned above exist in relation to the factors that influence the said dissimilarities. Below, we will examine these diametrically opposed positions presented by some of the most influential scholars in the field.

\section{Gender and language: difference, dominance, or similarity?}

As we mentioned above, researchers are not in agreement as to whether there are differences in language use between men and women, and if such divergences exist to what causes them. We will begin with the scholars who are in favour of what may be called the difference hypothesis.

According to Penelope Eckhert and Sally McConnell-Ginet ${ }^{4}$, one can distinguish two approaches to the issue of gender-based differences which we will describe here using two words, i.e. difference and dominance. These propositions aim at explaining the divergences in the behaviour and language use of males and females.

According to the first, difference model, the discrepancies are the result of the fact that boys and girls live and grow up in different 'subcultures' that are analogous to various existing 'subcultures' functioning within groups that come from different social and economic backgrounds 5 . This is the reason why one is faced with different standards and various conventions for verbal interactions.

It is easy to guess that the second view results from the idea that male dominance and the disadvantageous position of women within the patriarchal society influences the ways women behave and express themselves both verbally and non-verbally.

One of the scholars who emphasizes the differences in language use between men and women that is resultant from male dominance is Kwiryna Handke. She suggests that the disadvantageous position of women in society manifests itself not only in verbal behaviour, but also on the very fabric of language, i.e. its structure.

${ }^{4}$ P. Eckert, S. McConnell-Ginet, Language and Gender, Cambridge: Cambridge University Press 2003, DOI: http://dx.doi.org/10.1017/CBO9780511791147, p. 1.

5 Ibidem, p. 2. 
She points to that fact that in the Polish language the masculine grammatical gender (formy męskoosobowe, or translated literally male forms) is privileged in relation to the feminine gender (formy niemeskoosobowe, or literally translated non-male forms), which are treated as derivatives of these forms. It is clear that in Polish feminine forms are marked. The same holds true about the English language ${ }^{6}$.

Sociolinguists report many examples attesting to the existence of divergent, gender-based standards for verbal interaction. For example, Peter Trudgill points to the fact that in the case of some primitive tribes, such as Siberian Chukchi or African Zulu, one may literally speak of women using different language (variety or gender dialect to be precise) than men. It has been reported that in the case of Zulu, a wife is not allowed to mention the name of her father-in-law or his brothers, and she might be put to death if she broke this taboo 7 : "[...] it appears that this process could go as far as to include particular sounds of the language. Say, for example, that the tabooed name contained the sound $/ \mathrm{z} /$. This might mean, apparently, that the woman in question would not be able to use a word like amnazi 'water' without converting it to a form without the tabooed sound, amandabi"s.

Authors multiply similar examples, which seems to confirm the dominance hypothesis. However, one has to point out that in societies where the system of family is largely patriarchal and usually based on superstition; thus, dominance comes as somehow 'natural'.

Nevertheless, we think that it would be very hard to treat both approaches mentioned below independently. That is to say, as Eckhert and McConnell-Ginet suggest, it is extremely difficult to separate the differences that are a result of upbringing from the ones that arise from the dominant position of men in society. According to the scholars, these phenomena are inextricably linked ${ }^{9}$. Moreover, Eckhert and McConnell-Ginet suggest that systematic differences in verbal behaviour between males and females can only be accounted for through culture. They imply that gender has a negligible effect on male and female behaviour. It is the society that imposes the gender dichotomy (or the gender binary) at birth ${ }^{10}$. Deborah Cameron adds that "the contrast between 'dominance' and 'difference' is a false opposition: gender as a social system is about both simultaneously"11.

${ }^{6}$ K. Handke, Socjologia języka, Warszawa 2008, p. 147.

7 P. Trudgill, Sociolinguistics: an Introduction to Language and Society, $4^{\text {th }}$ ed., London: Penguin Books Ltd. 2000, pp. 66-69.

8 Ibidem, p. 67.

9 P. Eckert, S. McConnell-Ginet, op. cit., p. 2.

10 Ibidem, p. 15.

11 D. Cameron, The Myth of Mars and Venus, Oxford-New York: Oxford University Press 2007, p. 78. Emphasis added. 


\section{Gender similarities hypothesis}

It might seem that the question of dissimilarities in language use between men and women is undeniable. There are, however, scholars who disagree with views such as the ones mentioned above and stand out against the agreed consensus. One such scholar is Deborah Cameron. The author of the book entitled The Myth of Mars and Venus debunks some, in her opinion, false beliefs related to the notion of gender. Cameron opposes the view that male and female speech greatly differs. Even though, she does not deny that there may be some differences between men and women using language. However, Cameron argues that the discrepancies, when they are present, are not as significant as one may expect. According to the author, the main mistake researchers make is that while investigating the ways both sexes use language, they draw far reaching conclusions based on false assumptions. In Cameron's view, many researchers neglect meticulous analysis in favour of oversimplification. She states that: "What it means to be a man or a woman - and therefore what it means to talk like one - is always affected by the other attributes that define a person: their age, class, ethnicity, nationality, education, occupation, sexuality, politics, religious and subcultural allegiances"12.

In other words, many researchers tend to avoid a detailed analysis of the extralinguistic context. We fully agree with Cameron that conducting context analysis is essential to fully understand the phenomena in question. It is clear for us that any analysis lacking the parameter of context is doomed to be erroneous from the point of view of methodology - even if the conclusions turn out to be correct. Strictly speaking, the method has to be scientific, otherwise it is guessing.

Another question mentioned by Cameron is the tendency for what one may call 'unjustifiable overgeneralization'. We understand that inductive reasoning is prevalent in the humanities, but exactly for this reason any conclusions and generalisations have to be formulated very carefully. Also on this point we have to agree with the author.

Furthermore, Cameron points out that "linguistic behavior is only meaningful in context"13, which is a very important constatation as: "In context, for instance, interrupting someone may be rude or domineering behavior - a way of silencing and belittling them - or it may be supportive behavior, signaling enthusiasm for what they are saying"'14.

\footnotetext{
12 Ibidem, p. 53.

13 Ibidem, p. 45.

14 Ibidem.
} 
Therefore, simply counting the instances of interruption is insufficient. Such research is only quantitative, whereas it should be both, qualitative and quantitative in order to be meaningful. One has to correctly interpret the emotional attitudes of interlocutors towards one another.

Moreover, Cameron draws attention to the fact that many researchers simply omit "the fact that the variation exists within each gender group as well"15. She propounds the view "that there is at least as much variation within each gender group as there is between the two" 16 .

Due to the limited volume of this paper, we are unable to present all of the myths enumerated by the author of The Myth of Mars and Venus. However, one of the myths is so prevalent among researchers working in both the difference and dominance paradigms (or even treated as an axiom by some of them) and so deeply rooted in popular culture that it is really worth mentioning. This widespread opinion that Cameron dismisses, states that women talk more than men. It started with a popular science book entitled The female brain, published in 2006, where the author claims that women, on average, utter 20000 words a day, while men utter only 7000 . As it turned out, these numbers were not supported by any actual research. In this way, the damage was done and 'the data' are still often quoted in other papers ${ }^{17}$.

Cameron carried out an extensive meta-analysis of gender difference in verbal/ communicative behaviour and came to a conclusion that the differences she had found were so insignificant that "in almost every case, the overall difference made by gender is either small or close to zero"18.

In our opinion, and as Cameron rightly notices, one has to be pretty careful with any far reaching generalisations. However, based on the analysis provided by the author, it is safe to state that men and women who come from a similar cultural background have much more in common in terms of verbal behaviours than it might be suggested by the results of any of these studies when looked at independently.

\section{Context as a parameter in sociolinguistic analysis}

This might seem obvious, but no interaction happens in a void. As Erving Goffman argues, interlocutors enter a conversation with a set of assumptions, previous experiences, stereotypes and ready-made schemas, and depending on the addressee, they tailor the way they want to be perceived. In other words, they

\footnotetext{
15 Ibidem.

16 Ibidem, p. 44.

17 Ibidem, p. 20.

18 Ibidem, p. 43.
} 
put on masks appropriate to their social status and a given situation. Interlocutors adapt the way they speak, the words they use, but also create a persona through presentation and non-verbal behaviours in a more or less conscious manner ${ }^{19}$. The sole linguistic context has a tremendous influence on the progress of an interaction.

The linguistic context mentioned above is understood as the way words and expressions are related to the situation in the external world ${ }^{20}$. However, this definition does not fully capture the complexity we are dealing with, this is why it needs further elaboration. This is why we will now look at the definition proposed by Ann Hewings and Martin Hewings who emphasise the significance of both linguistic and extralinguistic elements of context.

Hewings and Hewings provide a set of elements that constitute the context of an utterance. According to the authors, the context of an utterance comprises local linguistic context, wider linguistic context, local situational context and finally wider socio-cultural context. Moreover, they point out that context is characterized by dynamicity, i.e.:

Not only are utterances shaped by their context, in that they cannot be properly understood without reference to the context in which they occur, but utterances also shape their context in that they themselves form part of the context in which following utterances are to be understood. In other words, context is constantly being changed by the act of communication itself ${ }^{21}$.

The most noticeable changes can obviously be seen in co-text, which, however, does not mean that the accumulation of interactions in a given population cannot sometimes have an influence on the wider socio-cultural context - as language itself is a vehicle of culture.

We present the diagram below in order to illustrate how particular components of context interplay with one another (Figure 1):

19 E. Goffman, Człowiek w teatrze życia codziennego, trans. H. Datner-Śpiewak, P. Śpiewak, Warszawa 2008, pp. 31-105.

20 S. Lappin, An introduction to formal semantics, [in:] The Handbook of Linguistics, eds. M. Aronoff, J. Rees-Miller, Malden: Blackwell Publishers Ltd. 2001, DOI: http://dx.doi. org/10.1002/9780470756409.ch15, p. 369.

${ }^{21}$ A. Hewings, M. Hewings, Grammar and Context. An Advanced Resource Book, London-New York: Routledge 2005, pp. 20-23. 


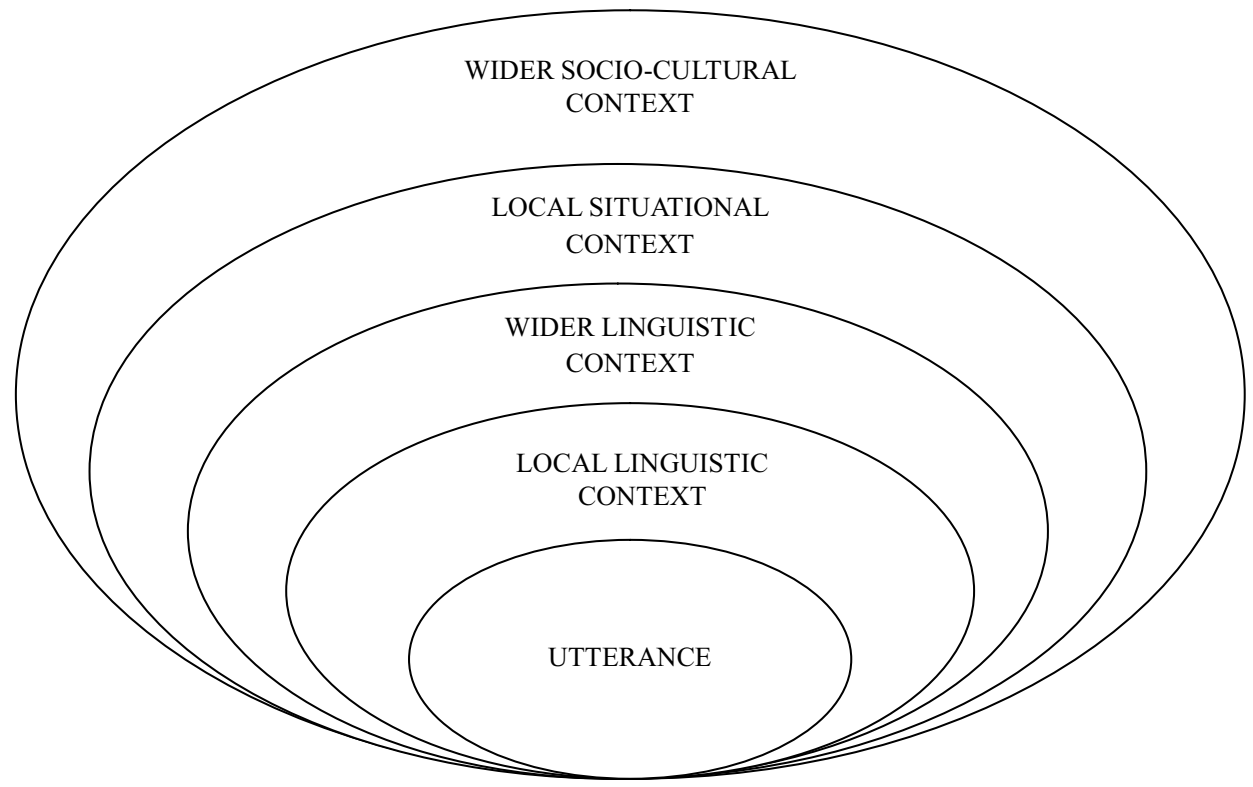

Figure 1. An utterance in its context, after Hewings and Hewings

Source: Grammar and Context. An Advanced Resource Book, London-New York 2005, p. 20.

\section{Materials and methods}

The study itself is based on quantitative and partly qualitative analysis. We took into consideration, among others, the number of the words uttered, turntaking, interrupting, and question tags. We also paid attention to the swear words used by interlocutors, and the overall number of words uttered.

Not without significance is the choice of the phenomena mentioned above. Scholars working within the sociolinguistic paradigm, and the ones who are interested in gender-related linguistic issues, study exactly the same phenomena. This is because they are strictly related to the deeply rooted stereotypes about gender and of how men and women use language.

As we mentioned before, we analysed the interviews carried out on Top Gear. The convention and the format of the interview in this particular show is predetermined. Thus, one can isolate particular stages (or parts) of the conversation. The time limit also has an influence on the timeframe of the interview. In other words, all of the analysed conversations have, more or less, the same duration. The said interviews come from 2008 and 2009. 


\section{Profiles of the interviewer and the interviewees}

The guests of the motoring show consist of well-known British celebrities, i.e. Fiona Bruce and Kate Silverton (Interview 1), Michael McIntyre (Interview 2), and Sienna Miller (Interview 3) ${ }^{22}$.

Below we provide information about the participants of the analysed Top Gear interviews. The data are provided in a form of a table for the sake of clarity. The table contains the most essential information about the interviewer and the interviewees. Parameters such as age, education, or occupation, in our opinion, may give important hints about the way interlocutors will behave in certain communication situations (Table 1).

Table 1. The key figures in the examined episodes

\begin{tabular}{|l|l|l|l|l|l|}
\hline Person & Gender & Role in the Interview & Occupation & \multicolumn{1}{|c|}{ Education } & Born \\
\hline $\begin{array}{l}\text { Fiona } \\
\text { Bruce }\end{array}$ & Female & Interviewee & $\begin{array}{l}\text { BBC } \\
\text { presenter }\end{array}$ & Oxford graduate & 1964 \\
\hline $\begin{array}{l}\text { Jeremy } \\
\text { Clarkson }\end{array}$ & Male & Interviewer & $\begin{array}{l}\text { Motor } \\
\text { journalist, } \\
\text { writer }\end{array}$ & $\begin{array}{l}\text { Expelled from Rapton } \\
\text { School before sitting his } \\
\text { A-levels }\end{array}$ & 1960 \\
\hline $\begin{array}{l}\text { Michael } \\
\text { McIntyre }\end{array}$ & Male & Interviewee & $\begin{array}{l}\text { Stand-up } \\
\text { comedian }\end{array}$ & $\begin{array}{l}\text { Studied at Edinburgh } \\
\text { University for one year }\end{array}$ & 1976 \\
\hline $\begin{array}{l}\text { Sienna } \\
\text { Miller }\end{array}$ & Female & Interviewee & Actress & $\begin{array}{l}\text { Studied at The Lee } \\
\text { Strasberg Theatre and } \\
\text { Film Institute }\end{array}$ & 1981 \\
\hline $\begin{array}{l}\text { Kate } \\
\text { Silverton }\end{array}$ & Female & Interviewee & $\begin{array}{l}\text { BBC } \\
\text { presenter }\end{array}$ & $\begin{array}{l}\text { Graduated from } \\
\text { the University of } \\
\text { Durham with a BSc in } \\
\text { Psychology }\end{array}$ & 1971 \\
\hline
\end{tabular}

The mutual relationship between the interlocutors can be described as positive, which in turn translates into the style of interaction. The format of the show, even though it is set as we mentioned above, is in fact very casual. Guests discuss various topics (not only the ones related to the automotive industry). It has to be mentioned that Top Gear as a show is far from the seriousness presented by Radio 4, the "high-brow" $\mathrm{BBC}$ radio station.

We are aware, at the same time, that from the methodological standpoint, the individuals mentioned above do not constitute the best cross-section of the population. Thus, our conclusions cannot be applied to all men and women, or even to the British society as a whole, but only to a small part of it.

22 See: our unpublished MA thesis for further divagations on the methodological nature of our analysis. 


\section{Context analysis}

Below, we present our analysis based on the division proposed by Hewings and Hewings $^{23}$. As the most important for our analysis are the non-linguistic elements of context, we begin with the description of the wider socio-cultural context. Next, we will investigate the local situational context of the interviews. Then, we will go on to describe the wider linguistic context of the interviews, and the local linguistic context of the utterances present in the interviews. In other words, we will start with the less dynamic elements of context understood as a whole, moving to the elements that change visibly in the course of interaction (i.e. co-text).

The wider socio-cultural context in the case of the analysed interview can be broadly defined through the notion of culture, understood as the totality of material and spiritual property of a populace, nation, epoch; the level of development of societies, groups, or individuals in a given period; the level of moral and intellectual development; manners, refinement, tact $^{24}$. By this, we may understand the sum of language, history, religion, art, politics and other elements that form the notion. In the case of the analysed material, we can state that the wider socio-cultural context is characterized by cultural Anglocentrism, including a specific view on history highlighting the important historical role of the British Empire.

Narrowing down the notion in question, we can state that the show is addressed to the members of the middle class who are interested in cars and car-related topics. This may seem strange, given the fact that most of the cars presented on the show are not within the reach of the middle class; however, with the style, the language used, the issues tackled, and the fact that the three presenters originally come from the middle class, it becomes less surprising.

In short, the wider socio-cultural context of the material taken from the British television series Top Gear, may be described as belonging to the millennium turn culture of the United Kingdom.

The local situational context of the analysed material can be elaborated with the use of a set of parameters devised by Dell Hymes. He organises this set into a checklist using the mnemonic 'SPEAKING'. In the acronym ' $S$ ' stands for setting and scene, which includes time, place and concrete physical circumstances of the event. 'P' refers to the participants. The following ' $E$ ' stands for ends, or the purposes or goals of the event. A refers to act sequence, or the form and content of the event. The letter ' $\mathrm{K}$ ' stands for key, which is the tone of a communicative act, e.g. serious or painstaking. 'I' stands for instrumentalities. These include the

${ }^{23}$ A. Hewings, M. Hewings, op. cit.

24 W. Kopaliński, Słownik wyrazów obcych i zwrotów obcojęzycznych, $25^{\text {th }}$ ed., Warszawa 1999, p. 283. 
channel in which communication takes place, e.g. speech or writing. ' $N$ ' refers to norm of interaction and interpretation, e.g. the norms associated with speaking to a stranger. Finally, the letter ' $G$ ', which stands for genre (a poem, sermon or a joke $)^{25}$. We present the local situational context of the analysed language material in the form of a table below (Table 2):

Table 2. The local situational context of the three analysed interviews

\begin{tabular}{|l|l|}
\hline \multicolumn{2}{|c|}{ Interview 1/Interview 2/Interview 3 } \\
\hline Setting & $\begin{array}{l}\text { Place: Top Gear studio, Airdate: Interview 1 - 13 July 2008 (Series 11 Episode 4) } \\
\text { Interview 2 - 5 July 2009 (Series 13 Episode 3) } \\
\text { Interview 3 - 19 July 2009 (Series 13 Episode 5) }\end{array}$ \\
\hline Participants & The profiles of the interviewer and the interviewees above \\
\hline Ends & Entertainment \\
\hline $\begin{array}{l}\text { Act } \\
\text { sequence }\end{array}$ & $\begin{array}{l}\text { The interview is a part of the show, usually takes place in the middle of the } \\
\text { programme, after video materials about cars, and before the rest of the show. } \\
\text { Top Gear interviews follow the same pattern. The interview starts with the } \\
\text { driving a 'reasonably priced car' around the track (on time), and ends with } \\
\text { a goodbye. }\end{array}$ \\
\hline Key & Relaxed \\
\hline $\begin{array}{l}\text { Instrumen- } \\
\text { talities }\end{array}$ & Speech \\
\hline $\begin{array}{l}\text { Norms of } \\
\text { interaction }\end{array}$ & Norms associated with interaction during a relaxed interview \\
\hline Genre & An interview \\
\hline
\end{tabular}

The wider linguistic context is modeled by other texts of culture. One can narrow down these texts to the media reality experienced by the audience of $T o p$ Gear who live in the UK. This reality includes the language of politics (e.g. popular expressions related to the higher levels of context), the social and societal situation and language realisations in different media, such as internet memes, and so on. One of the references of this kind is a comment of the interviewer about Max Mosley (Interview 1). In order to interpret it correctly - not only the surface structure, but also what it means (i.e. its relation with the external world) - one has to be well acquainted with the source culture. Because episodes of Top Gear are characterised by relative cohesion, one has to be familiar with the structure of previous episodes that constitute inseparable parts of the entirety.

25 A. Hewings, M. Hewings, op. cit., pp. 27-28. 
When it comes to the last level, i.e. the local linguistic context (or co-text), it comprises particular utterances that create unique idiolects of the speakers-hearers. It can be said that certain properties of idiolects are stable despite the fact that interlocutors put on masks and sometimes 'act' (depending on the context ${ }^{26}$. For example, one can state that the register, the vocabulary used, or even the number of words uttered by Jeremy Clarkson is almost the same in the three analysed interviews.

\section{Analysis of the language material in relation to gender}

The first parameter we would like to have a look at is the overall number of words uttered by each interlocutor in the analysed interviews. We provide three tables with data concerning the number of words and turns for the interviews in question below (Table 3-5).

Table 3. Words and turns in Interview 1

\begin{tabular}{|c|c|}
\hline $\begin{array}{l}\text { Interview 1: Fiona Bruce, Kate Silverton, Jeremy Clarkson } \\
\text { Jeremy Clarkson }\end{array}$ & \\
\hline Number of words: & \\
\hline - with introduction of the participant & 1076 \\
\hline - without the introduction & 1023 \\
\hline $\begin{array}{l}-\quad \text { without the introduction and without the } \\
\text { commentary during the video from 'the lap' }\end{array}$ & 772 \\
\hline Fiona Bruce & \\
\hline Number of words: & \\
\hline$-\quad$ overall & 349 \\
\hline $\begin{array}{l}\text { - without the commentary during the video from 'the } \\
\text { lap' }\end{array}$ & 318 \\
\hline Kate Silverton & \\
\hline Number of words: & \\
\hline$-\quad$ overall & 427 \\
\hline $\begin{array}{l}\text { - without the commentary during the video from 'the } \\
\text { lap' }\end{array}$ & 417 \\
\hline $\begin{array}{l}\text { Jeremy Clarkson } \\
\text { Number of turns (during the whole interview) }\end{array}$ & 85 \\
\hline $\begin{array}{l}\text { Fiona Bruce } \\
\text { Number of turns (during the whole interview) }\end{array}$ & 44 \\
\hline $\begin{array}{l}\text { Kate Silverton } \\
\text { Number of turns (during the whole interview) }\end{array}$ & 35 \\
\hline
\end{tabular}

26 E. Goffman, op. cit., pp. 31-105. 
Table 4. Words and turns in Interview 2

\begin{tabular}{|c|c|}
\hline \multicolumn{2}{|c|}{ Interview 2: Michael McIntyre, Jeremy Clarkson } \\
\hline \multicolumn{2}{|l|}{ Jeremy Clarkson } \\
\hline \multicolumn{2}{|l|}{ Number of words: } \\
\hline - with introduction of the participant & 597 \\
\hline - without the introduction & 534 \\
\hline $\begin{array}{l}\text { - without the introduction and without the } \\
\text { commentary during the video from 'the lap' }\end{array}$ & 417 \\
\hline \multicolumn{2}{|l|}{ Michael McIntyre } \\
\hline \multicolumn{2}{|l|}{ Number of words: } \\
\hline$-\quad$ overall & 1183 \\
\hline $\begin{array}{l}\text { - without the commentary during the video from 'the } \\
\text { lap' }\end{array}$ & 1172 \\
\hline Jeremy Clarkson & \\
\hline Number of turns (during the whole interview) & 39 \\
\hline Michael McIntyre & \\
\hline Number of turns (during the whole interview) & 38 \\
\hline
\end{tabular}

Table 5. Words and turns in Interview 3

\begin{tabular}{|c|c|}
\hline \multicolumn{2}{|c|}{ Interview 3: Sienna Miller, Jeremy Clarkson } \\
\hline \multicolumn{2}{|l|}{ Jeremy Clarkson } \\
\hline \multicolumn{2}{|l|}{ Number of words: } \\
\hline - with introduction of the participant & 861 \\
\hline - without the introduction & 813 \\
\hline $\begin{array}{l}\text { - without the introduction and without the } \\
\text { commentary during the video from 'the lap' }\end{array}$ & 717 \\
\hline \multicolumn{2}{|l|}{ Sienna Miller } \\
\hline \multicolumn{2}{|l|}{ Number of words: } \\
\hline$-\quad$ overall & 603 \\
\hline $\begin{array}{l}\text { - without the commentary during the video from 'the } \\
\text { lap' }\end{array}$ & 591 \\
\hline Jeremy Clarkson & \\
\hline Number of turns (during the whole interview) & 72 \\
\hline Sienna Miller & \\
\hline Number of turns (during the whole interview) & 72 \\
\hline
\end{tabular}

As one can see from the material above, the number of words uttered by the interlocutors is not particularly different. In the first interview, the lower number of words uttered by women is the result of the fact that the number in question has to be divided by two women. Moreover, the relatively higher number of words uttered by Jeremy Clarkson is due to the fact that he has a specific role in the interview, i.e. he is the host. What is more, he interviews two people at the same time. Thus, if we divide the number of the words he uttered into 2, there will be around 386 words for each guest. 
When it comes to turn-taking, due to the fact that the conversation takes place between three individuals, we can add 35 (Silverton) and 44 (Bruce) and compare the result to 85 (Clarkson). As one can see, there is no significant discrepancy between the interlocutors. This is pretty similar to the two remaining interviews, i.e. 39 vis a vis 38 in the case of the second interview, and 72 and 72 in the case of the third interview.

In our opinion, the most interesting is Interview 2. It seems to falsify the opinion that women talk more than men. Michael McIntyre utters as many as 1172 words in a relatively short space of time. One can compare this result to the number of words uttered by the rest of the interlocutors in all three interviews. However, McIntyre's style of communication is rather a result of his emploi (he is a stand-up comedian) and his traits of character rather than the gender role.

Considering the above, we have to conclude after Cameron that certain differences follow from interlocutors' character and not from their gender identity. As illustrated by the language material, one cannot definitely state that women, as a group, demonstrate homogeneous behaviours, for example in the case of the number of words uttered or turn-taking.

In the same way, it is impossible to give definite answers when it comes to interrupting. It is worth noting that in the analysed interviews, interruptions may be described as supportive behavior, that signals enthusiasm for what the other person is saying. Never is it a sign of rudeness or domination. As Janet Holmes suggests, men usually interrupt more often and are perceived as less polite ${ }^{27}$. We cannot agree with the author on this point, at least it cannot be a conclusion following from our analysis. When analyzing Interviews 1 and 2, it is difficult to find examples of interruptions. In the case of Interview 3 , however, there are some examples of interruptions. What may seem surprising in light of Holmes's research, it is a woman who interrupts the male host. As we pointed out before, none of the interruptions was a sign of rude or face threatening behaviour.

When it comes to overusing question tags, which is often associated with women ${ }^{28}$, in the analysed interviews, none of the women used them - not even once. The male host, on the other hand, used two different kinds of question tags (over the three interviews). Similarly, as in the case of other linguistic phenomena, their usage depends on the role of the interlocutor, lack of confidence (compare: the usage of question tags) or his or her specific idiolect, rather than on his or her gender.

27 J. Holmes, Women, Men and Politeness, London-New York: Longman Group UK Ltd. 1995, pp. 52, 227.

${ }_{28}$ Compare question tags: ibidem, p. 86. About question tags: M. Swan, Practical English Usage, Oxford: Oxford University Press 1995, p. 479. 


\title{
Conclusions
}

The analysis above seems to corroborate the views expressed by Cameron. Despite the fact that we are aware of the methodological limitations, some conclusions are clear. One conclusion may be that the way people use language is highly individualized. Moreover, gender is only one of many aspects to be analysed, and it is - in our opinion - not the most important one. Other far reaching generalisations may be well-founded due to the influential role of the mass media - here - the extremely popular automotive television show Top Gear. Even though our conclusions are narrowed down to a very specific context, the language material presented seems to suggest that the differences in language use between men and women that may sometimes appear (and were not present in the interviews analysed by us) are not a result of natural qualities of male or female linguistic behaviours. Some models of interactions indirectly promoted by the media can influence the standards of language behaviours adopted in everyday life. Despite the influence of testosterone on the human foetus, or the resulting differences in the structure of the brain and brain function, it appears that in the process of social development of individuals who grow up in Western societies some differences in language use (if they are present) are almost imperceptible. Our conclusions have to be limited to societies where the patriarchal model of family ceased to play a significant role in relation to other, less developed, traditional cultures, where the differences are likely to be significant. We may conclude, however, that with the development of civilizations, the differences that are biology-driven will eventually stop to play an important role in verbal interactions.

\section{Streszczenie}

\section{Clarkson jest kobietą, czyli o problematyce płci kulturowej w języku na przykładzie wywiadów przeprowadzonych $\mathrm{w}$ brytyjskim programie motoryzacyjnym Top Gear}

\begin{abstract}
Niniejszy artykuł podejmuje kwestię różnic w użyciu języka, wynikających z płci interlokutorów. Przez analizę kluczowych pojęć (takich jak np. kontekst) oraz przegląd poglądów i teorii badaczy zajmujących się socjolingwistyką i problematyką gender autor stara się odpowiedzieć na pytanie, czy istnieją systematyczne różnice w użyciu języka wynikające z płci. Opierając rozważania na pojęciach, poglądach i teoriach wspomnianych powyżej, przeprowadza analizę materiału językowego pochodzącego z popularnego programu motoryzacyjnego Top Gear.
\end{abstract}

Słowa kluczowe: płeć biologiczna; płeć kulturowa; socjolingwistyka; gender studies 


\section{Summary}

The present article investigates the issue of gender differences in language use. We look at some essential notions indispensable in the analysis of language use such as context. We also present some of the ideas and theories related to the question whether there are systematic differences in the ways men and women use language introduced by scholars working within the frame of gender studies and sociolinguistics. The aforementioned ideas are integrated into our analysis of the linguistic material that comes from a popular motoring show Top Gear.

Keywords: gender; sex; sociolinguistics; gender studies

\section{Bibliography}

Cameron D., The Myth of Mars and Venus, Oxford-New York: Oxford University Press 2007.

Eckert P., McConnell-Ginet S., Language and Gender, Cambridge: Cambridge University Press 2003, DOI: http://dx.doi.org/10.1017/CBO9780511791147.

Goffman E., Człowiek $w$ teatrze życia codziennego, trans. H. Datner-Śpiewak, P. Śpiewak, Warszawa 2008.

Handke K., Socjologia języka, Warszawa 2008.

Hewings A., Hewings M., Grammar and Context. An Advanced Resource Book, London-

New York: Routledge 2005.

Holmes J., Women, Men and Politeness, London-New York: Longman Group UK Ltd. 1995. Kopaliński W., Słownik wyrazów obcych i zwrotów obcojęzycznych, $25^{\text {th }}$ ed., Warszawa 1999. Lappin S., An introduction to formal semantics, [in:] The Handbook of Linguistics, eds. M. Aronoff, J. Rees-Miller, Malden: Blackwell Publishers Ltd. 2001,

DOI: http://dx.doi.org/10.1002/9780470756409.ch15, pp. 369-393

Plunkett J., Top Gear driven from Argentina after Jeremy Clarkson number plate row, "The Guardian" [online], 3 October 2014. Available on the internet: www.theguardian.com/ media/2014/oct/03/top-gear-argentina-jeremy-clarkson-bbc [accessed: 20 April 2015].

Płeć kulturowa, [in:] Encyklopedia PWN, [online]. Available on the internet: http://encyklopedia.pwn.pl/haslo/plec-kulturowa;3958385.html [accessed: 3 March 2015].

Summary text of BBC's report into Jeremy Clarkson 'fracas', "The Guardian" [online], 25 March 2015. Available on the internet: www.theguardian.com/media/2015/mar/25/ jeremy-clarkson-fracas-report-full-text-bbc-macquarrie [accessed: 20 April 2015].

Swan M., Practical English Usage, Oxford: Oxford University Press 1995.

Trudgill P., Sociolinguistics: an Introduction to Language and Society, $4^{\text {th }}$ ed., London: Penguin Books Ltd. 2000. 